\title{
Effects of feeding frequency on specific growth of tilapia (Oreochromis niloticus) fingerlings in hapa nets in fish ponds at in Kenya
}

\begin{abstract}
Tilapias are mainly freshwater fish, inhabiting shallow streams, ponds, rivers and lakes, and less commonly found in brackish water. O. niloticus is the most commonly farmed and widely spread species due to its fast growth rate, higher fecundity and better flesh quality. The species is native to the Nile drainage from its headwaters in Ethiopia and Kenya to the Nile Delta of Egypt, the Niger drainage, and lakes and streams once historically connected to these drainages. Globally, total farmed tilapia productions are averagely 3.8 million metric tons, way above salmonids and catfishes. Fingerlings of Nile tilapia, Oreochromis niloticus, were reared at three feeding frequencies (1,2 and 3times/day) with a control in which fry were not fed in hapa nets at University of Eldoret fish farm's fish pond for 4-weeks. Fish were fed with $35 \%$ protein diet at $5 \%$ of fish biomass. There was a significant difference $(\mathrm{P}<0.05)$ between feeding frequency of three times daily and other feeding frequencies of one and two times daily with respect to final mean weight, specific growth rate (SGR) and survival. Average daily gain (ADG), feed conversion and feed conversion efficiency were statistically similar for three times` daily feeding frequencies and were higher than once and twice daily feeding frequencies. Feeding frequency of three times daily was the most optimum in terms of growth, survival and feed conversion efficiency of the fish.
\end{abstract}

Keywords: oreochromis niloticus, nile drainage, specific growth rate (SGR), average daily growth (ADG), fecundity
Volume 7 Issue 2 - 2018

\author{
George Wasonga Alal \\ University of Eldoret, Department of Fisheries and Aquatic \\ Sciences, Kenya
}

Correspondence: George Wasonga Alal, University of Eldoret, School of Natural Resource Management, Department of Fisheries and Aquatic Sciences, Email gwasonga2005@yahoo.com

Received: February 20, 2018 | Published: April 02, 2018

\section{Introduction}

Tilapias are mainly freshwater fish, inhabiting shallow streams, ponds, rivers and lakes, and less commonly found in brackish water. Almost 100 species of fish are referred to by the common name Tilapia but only three species feature significantly in aquaculture: the Nile tilapia, Oreochromis niloticus (Linnaeus 1758), the Mozambique tilapia, O. mossambicus, and the Blue tilapia $O$. aureus. Of the three, $O$. niloticus is the most commonly farmed and widely spread species, due to its fast growth rate, higher fecundity and better flesh quality. This species is native to the Nile drainage from its headwaters in Ethiopia and Kenya to the Nile Delta of Egypt, the Niger drainage, and lakes and streams once historically connected to these drainages. ${ }^{2}$ Globally, total farmed tilapia production averaged 3.2 million metric tons in $2010,{ }^{3}$ way above salmonids and catfishes.

A natural diversity of $O$. niloticus strains exists in Kenya, spread in the lakes such as Victoria, Baringo, Turkana, Kenyatta and Jipe, and major rivers in the country. ${ }^{4}$ Lake Victoria is the main source of $O$. niloticus, with annual landing of the species on the Kenyan side averaging 6,081MT In the year 2012..$^{5}$ However, ample supply of the species from wild habitats is no longer guaranteed, as these ecosystems are under severe pressure resulting from pollution, overfishing, habitat fragmentation and destruction. ${ }^{7}$ This calls for alternative measures, such as a focus on aquaculture, to enhance fish production for improved food security, income and livelihoods, consistent with the need to conserve wild resources and attain the first Millennium Development goal, in the country. Locally, a total of
16,115 metric tonnes of tilapia were produced by farmers in Kenya in 2012 (Kenya Fisheries Bulletin, 2012)..$^{5}$ Tilapia is mainly produced in polyculture with catfish, Clarias gariepinus, in small holder units, and the harvest is mainly sold to neighbors and on small market centres. Apart from its fast growth, high fecundity and ease of reproduction in captivity, ${ }^{3} \mathrm{O}$. niloticus also commands a high market demand, and therefore could potentially help increase fish production and health among rural communities.

Tilapia culture in Kenya and many African countries is constrained by inadequate availability of high quality fingerlings or seed material for stocking in ponds. This could be related to the fact that seed production technologies are not well developed. In particular, farmers fail to feed the fry in hatcheries, leading to poor growth and low survival. The importance of feed in aquaculture is reflected in that feeding of fish accounts for $60 \%$ of the production costs. This study assessed the efficacy of different feeding frequencies for tilapia fry, in order to enhance early growth and survival of fry.

Feed and labor are the two highest variable costs in fish culture operations. Both can be reduced through feeding management. The traditional management strategy for maximizing growth is by maximizing feeding. However, wasted feed can account for $5-30 \%$ of the feed offered and up to $50 \%$ of the total solid waste produced. ${ }^{8,9}$ The result is decreased efficiency, degraded water quality, and increased operating expenses. Good feeding management, including appropriate frequency, can reduce overfeeding and maximize efficiency. Based on feeding behavior, physiology, and gastrointestinal morphology of wild fish, it has been reported that Nile tilapia (Oreochromis niloticus) 
require frequent meals. ${ }^{10,11}$ Relative to farm raised fish, wild tilapia exhibit greater voluntary activity associated with seeking food. ${ }^{12}$ The higher quality, consistency, and availability of pelleted feeds may reduce the need for frequent feedings. In intensive systems, frequent feedings may not be economic due to increased labor costs. The objective of this study was to examine the effects of feeding frequency on $O$. niloticus fingerlings fed to satiation by evaluating consumption, growth, and feed efficiency.

\section{Materials and methods}

\section{Study area}

The research was done at the University of Eldoret's fish farm situated along Eldoret- Iten- Ziwa road, 9km from Eldoret town. The fish farm lies on $0,32^{`} \mathrm{~N}, 35,12^{`} \mathrm{E}$ at an altitude $2140 \mathrm{~m}$ above sea level. The experiment was carried out in net hapas of $1 \mathrm{X} 1 \mathrm{X} 1\left(1 \mathrm{~m}^{3}\right)$, suspended in earthen pond $15 \mathrm{X} 20\left(300 \mathrm{~m}^{2}\right)$, for a period of 24 days.

\section{Experimental design}

A mixed sex population of $O$. niloticus was obtained from the University of Eldoret fish farm ponds. The initial weight of tilapia fingerlings was taken and their average determined. They were stocked at 50 fingerlings per net hapa. During the experiment, four feeding frequencies were evaluated with three replicates per treatment. They were fed 1,2 and 3 times a day and a control which was not fed. The experimental units were replicated bringing the total number of stocked hapas to nine (9) suspended in one pond measuring 15 by 30 . Water quality parameters i.e. $\mathrm{PH}$, dissolved oxygen and temperature were also taken during every sampling period. Mean fish weight at stocking was $0.9 \pm 0.4 \mathrm{~g}$. Prior to the start of the experiment, the fish were allowed a one-week acclimation period during which they were not fed. The pond in which net hapas were suspended was fertilized after every two weeks at a ratio of $3 \mathrm{~g} / \mathrm{m}^{2}$ UREA: $2 \mathrm{~g} / \mathrm{m}^{2}$ DAP, to stimulate the growth of natural food (plankton) for the fish in the water.

\section{Treatments}

The experimental treatments were the feeding frequencies; fish not fed at all, fish fed once daily (at 10:00 am.), twice daily (10:00 am and 2:00 pm), and three times daily (08:30 am, 11:30 am and 2:30 pm daily). The experiment lasted 24days.

\section{Feeds used}

The feed were calculated using Pearson's square method and formulated at $35 \%$ c.p, with these as the major ingredients;

a. Fish meal- crude protein $(66.7 \%)=1.44 \mathrm{~kg}$

b. Wheat bran- crude protein $(14.7 \%)=0.68 \mathrm{~kg}$

c. Cotton seed cake - crude protein $(36.0 \%)=1.44 \mathrm{~kg}$

d. Sunflower seed cake- crude protein $(36.0 \%)=1.44 \mathrm{~kg}$

$$
\text { Total }=5.00 \mathrm{~kg}
$$

Nile perch oil was added at $5 \%$ of the total formulated feeds weight for protein sparing effect on the fish and to improve the feed palatability and binding of the ingredients together. The formulated feed was pelleted using a pelletizer. The feed was sun-dried for four days to reduce the moisture content in the formulated feed. The feeds were then powdered to make them easy for the fish fingerlings to swallow.

\section{Data analysis}

Growth parameters were calculated as follows:

Body weight gain $(\mathrm{BWG})=$ final body weight $(\mathrm{g})$-initial body weight $(\mathrm{g})$.

Specific growth rate was computed as (SGR):

$S G R=\frac{\ln W_{2}-\ln W_{1} \times 100}{T}$

Where: $\mathrm{W}_{1}=$ initial weight $(\mathrm{g})$ at stocking, $\mathrm{W}_{2}=$ final weight $(\mathrm{g})$ at the end of experiment, $\mathrm{InW}_{2}-\mathrm{InW}_{1}=$ natural logarithms of both the final and initial weight of fish, $\mathrm{T}=$ duration (in days) of trial (Adewolu, 2008; Ogunji et al., 2008; Effiong et al., 2009).

Feed conversion ratio was computed as (Jhingran, 1991):

$$
F C R=\frac{\text { Total feed given }}{\text { Total weight gained by fish }}
$$

$$
\varnothing F E(\%)=1 / F C R * 100
$$

$$
A D G(g / f i s h / \text { day })=[A V W G(g) / \text { experimental period }(d)]
$$

$\emptyset$ Daily growth rate $(D G R)=($ final body weight $(g)$-initial weight $(g)) \times(100) /($ experimental period $\times$ initial weight $)$

$$
\text { Ø Survival rate }=\left(N_{t} \times 100 N_{0}-^{1}\right)
$$

\section{Results}

The growth parameters were measured and calculated as shown in Table 1. Body weight gain was higher at feeding twice $(0.90 \pm 0.78)$, feeding once $(0.60 \pm 0.81)$, feeding three times $(0.40 \pm 0.78)$ and lest when fish were not fed $(0.30 \pm 0.19)$. Specific growth for weight was also having similar trend as body weight gain with feeding twice at $1.11 \% \mathrm{BW}$ day- ${ }^{-1}$, feeding once $0.97 \% \mathrm{BW}$ day- ${ }^{1}$, feeding thrice at $0.70 \% \mathrm{BW}$ day $-^{-1}$ and least at $0.34 \% \mathrm{BW}$ day- ${ }^{1}$. Feeding once a day had the best feeding conversion ratio at 0.11 , feeding twice at 0.24 and feeding three times a day had 0.49 with control (no feeding) having no feeding conversion ration as it was not fed. Feeding three times a day had a higher Feeding conversion efficiency at $49.31 \%$, feeding two times a day at $23.93 \%$ and feeding one times a day $10.69 \%$ with control having $0 \%$. Average daily growth resulted in feeding two times a day having higher level at 1.41 , feeding once at 1.12 , feeding three times a day at 0.69 and control (no feeding) having the least at 0.49 . Feeding twice had the best daily growth rate at 2.32 , feeding once at 1.62 , feeding thrice at 1.13 and control had the least at 0.87 . Mean growth for the culture period of 24 days showed that feeding once a day had a higher growth at 1.48 , feeding twice at 1.28 , feeding thrice at 1.13 and least at 0.56 in the control treatment.

Condition factor of the tilapia fingerlings were calculated to ascertain their wellbeing during the entire period of the project. These were measured on a weekly basis and variation was monitored and mostly negative allometric growth as it was generally below condition factor of 3 (Table 2).

The condition factor was higher in the feeding two times a day at 1.82 , feeding three times a day had 1.78 , feeding once a day had 1.77 
and control (no feeding) having a condition factor of 0.82 (Figure 1).

Survival rate of the Nile tilapia fingerlings were calculate and feeding twice had the highest survival at $92 \%$, feeding once at $89 \%$, feeding three times at $87 \%$ and least in control at $65 \%$ (Table 3 ) (Figure 2). ${ }^{13,14}$

Table I Growth parameters of Tilapia (Oreochromis niloticus) fingerlings in experimental treatments (I, 2, 3 and 0 (control) feeding)

\begin{tabular}{|c|c|c|c|c|}
\hline \multirow[t]{2}{*}{ Growth indices } & \multicolumn{4}{|l|}{ Treatments } \\
\hline & Feeding once & Feeding twice & Feeding thrice & Control \\
\hline Initial body Weight (g) & $3.80 \pm 0.6$ & $3.40 \pm 0.6$ & $3.60 \pm 0.7$ & $3.10 \pm 0.6$ \\
\hline Final body Weight (g) & $4.40 \pm 0.7$ & $4.30 \pm 0.9$ & $4.00 \pm 0.9$ & $3.40 \pm 1.1$ \\
\hline Body weight gain (g) & $0.60 \pm 0.50$ & $0.90 \pm 0.78$ & $0.40 \pm 0.54$ & $0.30 \pm 0.11$ \\
\hline $\begin{array}{l}\text { Specific Growth Rate for weight (\%BW } \\
\text { day-I) }\end{array}$ & 0.97 & I.II & 0.70 & 0.34 \\
\hline Feed conversion ratio & 0.11 & 0.24 & 0.49 & 0.00 \\
\hline Feed conversion efficiency (\%) & 10.69 & 23.93 & 49.31 & 0.00 \\
\hline Average Daily Growth (ADG) & 1.12 & 1.41 & 0.69 & 0.49 \\
\hline Daily Growth Rate (DGR) & 1.62 & 2.32 & 1.13 & 0.87 \\
\hline Mean growth & 1.48 & 1.28 & 1.13 & 0.56 \\
\hline Standard deviation & 0.81 & 0.78 & 0.78 & 0.40 \\
\hline Variance & 0.65 & 0.60 & 0.60 & 0.16 \\
\hline
\end{tabular}

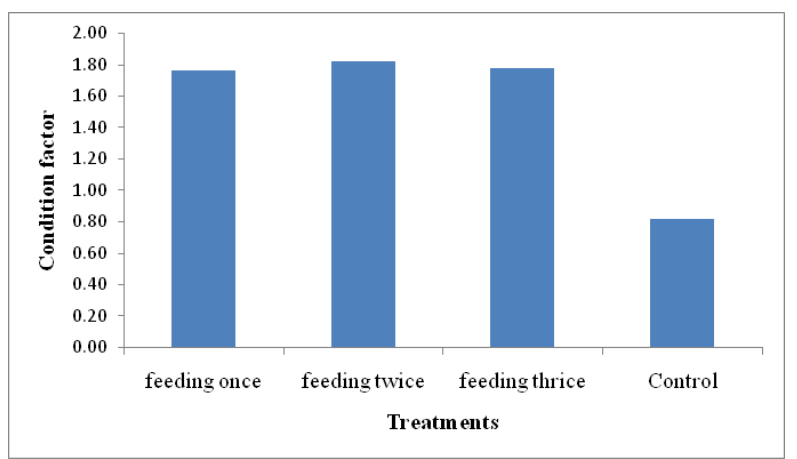

Figure I Condition factor of Nile Tilapia (Oreochromis niloticus) fingerlings under different feeding frequencies for 24 days.

Table 2 Condition Factor of Tilapia fingerlings subjected to different feeding frequencies for a period of 4 weeks or 24 days

\begin{tabular}{lllll}
\hline \multicolumn{2}{c}{ Condition factor } & & & \\
\hline Treatments & Ist week & 2nd week & 3rd week & 4th week \\
$\begin{array}{l}\text { Feeding one } \\
\text { times a day }\end{array}$ & $\mathrm{I} .9 \mathrm{I}$ & $\mathrm{I} .73$ & $\mathrm{I} .72$ & $\mathrm{I} .7 \mathrm{I}$ \\
$\begin{array}{l}\text { Feeding two } \\
\text { times a day }\end{array}$ & 2.20 & $\mathrm{I} .69$ & $\mathrm{I} .66$ & $\mathrm{I} .74$ \\
$\begin{array}{l}\text { Feeding three } \\
\text { times a day }\end{array}$ & $\mathrm{I} .87$ & $\mathrm{I} .88$ & $\mathrm{I} .65$ & $\mathrm{I}$ \\
\begin{tabular}{l} 
Control \\
\hline
\end{tabular} & $\mathrm{I} . \mathrm{I}$ & 0.67 & 0.67 & 0.77 \\
\hline
\end{tabular}

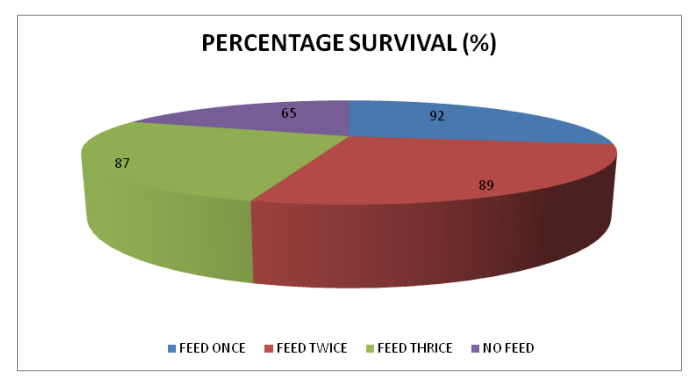

Figure 2 Percentage survival of Nile Tilapia (Oreochromis niloticus) fingerlings under different feeding frequencies for 24 days.

Table 3 Survival of Nile Tilapia (Oreochromis niloticus) fingerlings under different feeding frequencies for 24 days

\begin{tabular}{lllll}
\hline Parameters & Feed once & $\begin{array}{l}\text { Feed } \\
\text { twice }\end{array}$ & $\begin{array}{l}\text { Feed } \\
\text { thrice }\end{array}$ & No feed \\
\hline $\begin{array}{l}\text { Initial stock } \\
\begin{array}{l}\text { Survivors } \\
\text { Mortality }\end{array}\end{array} 1^{150}$ & 134 & 150 & 150 & 150 \\
$\begin{array}{l}\text { Percentage } \\
\text { mortality (\%) }\end{array}$ & 8 & 12 & 20 & 53 \\
$\begin{array}{l}\text { Percentage } \\
\text { survival (\%) }\end{array}$ & 89 & 11 & 13 & 35 \\
\hline
\end{tabular}

\section{Discussion}

In some fish species, the first food entering the stomach is the first food to leave. However, food eaten by tilapia can move past the stomach and enter directly into the intestine. Fish fed at 2-3 hour intervals eat more feed than their stomachs can hold. The extra feed 
eaten passes over the stomach and is considered wasted. The result is an increased cost of production and lower profits. Fish fed at 4-5 hour intervals eat nearly the same amount of feed needed to refill their stomachs. This suggests the optimal interval between feedings is $4-5$ hours, depending on the energy and composition of the diet. Increased feeding frequencies decrease aggressive behavior in some fish species, these, results in faster growth and less size variation.

However, there is a limit to the frequency that will result in benefits. There are many fish species that are less efficient when fed at short intervals. Evidence suggests tilapia fed too frequently utilize feed less efficiently.

Fish are sensitive to water quality. Feeding should be reduced or stopped if water quality falls below certain levels. Shortly after feeding, dissolved oxygen levels decline rapidly. Dissolved oxygen levels should be maintained above $5.0 \mathrm{ppm}$ for best growth. At dissolved oxygen levels between 3.0-5.0 ppm feeding should be reduced, and feeding should be stopped at dissolved oxygen levels below $3.0 \mathrm{ppm}$.

\section{Conclusion}

Tilapia is well suited for aquaculture. Tilapia grow rapidly and are fairly resistant to stress and disease. Earthen ponds are easy to build and therefore suitable for maximization of production efficiency. To maximize production efficiency and minimize costs, tilapia should be fed; nutritionally complete diets formulated to meet their dietary requirements, optimum crumbles or pellet size, optimum feeding rate ( $\%$ of fish body weight), and optimum time intervals (2-3 hours depending on the energy and composition of the diet); based on the size of the fish and the culture conditions

\section{Recommendations}

Feeding frequencies play an important role in the growth and survival of juvenile Oreochromis niloticus fishes. To maximize production efficiency and minimize costs, tilapia should be fed on nutritionally complete diets formulated to meet their dietary requirements, optimum crumbles or pellet size, optimum feeding rate ( $\%$ of fish body weight), and optimum time intervals (2-3 hours depending on the energy and composition of the diet); based on the size of the fish and the culture conditions. The fish should also be fed to satiation with minimal food wastage.

\section{Acknowledgments}

None.

\section{Conflict of interests}

The authors declare no conflict of interest.

\section{References}

1. Pullin RSV, Lowe-McConnell RH. The Biology and Culture of Tilapias. ICLARM Conference Proceedings 7. International Center for Living Aquatic Resources Management, Philippines: Manila; 1997.

2. Trewavas E. Tilapiine Fishes of the Genera Sarotherodon, Oreochromis and Danakilia. London: British Museum, Natural History, BHL; 1983.

3. Fitzsimmons K. Tilapia. The most important fish of the 21 st century. 2011.

4. Okeyo DO, Seegers L, De Vos L. Annotated checklist of the freshwater fishes of Kenya (excluding the lacustrine haplochromines from Lake Victoria). Journal of East African Natural History. 2003;92(1):11-47.

5. Kenya Fisheries Bulletin. Fisheries annual statistical bulletin. 2012.

6. Aloo PO. Biological diversity of Yala swamp lakes, with special emphasis on fish species composition, in relation to changes in the Lake Victoria basin Kenya: threats and conservation measures. Biodiversity Conservation. 2003;12(5):905-920.

7. Odada EO, Daniel OO, Kassim K, et al. Mitigation of environmental problems in Lake Victoria, East Africa: causal chain and policy options analyses. Ambio. 2004;33(1-2):13-23.

8. Warrer Hansen I. Evaluation of matter discharged from trout farming in Denmark. 1982; p. 57-63.

9. Cho CY, Hynes JD, Wood KR, HK Yoshida. Quantitation of fish culture wastes by biological (nutritional) and chemical (limnological) methods: the development of high nutrient dense (HND) diets. In: Cowey CB, Cho CY, editors. Nutritional Strategies and Aquaculture Waste. Proc. 1st Int. Symp. Nutritional Strategies in Management of Aquaculture Waste. Univ. Guelph, Ontario, Canada.1991. p. 37-49.

10. Moriarty DJW. The physiology of digestion of blue-green algae in the cichlid fish Tilapia nilotica. Journal of Zoology. 1973;171:25-40.

11. Jauncey K, Ross B. A Guide to Tilapia Feeds and Feeding. Inst. Aquaculture, Univ. Stirling, Stirling, Scotland.1982.

12. Gerking SD. Feeding Ecology of Fish, San Diego, California: Academic Press; 1994.

13. Moriarty DJW. The physiology of digestion of blue-green algae in the cichlid fish Tilapia nilotica. Journal of Zoology. 1973;171:25-40.

14. In: Alabaster JS editors. Report of the EIFAC Workshop on Fish-Farm Effluents. European Inland Fisheries Advisory Commission Technical Paper 41, Silkeborg, Denmark. 1981; p. 26-28. 